\title{
Preservation of Local Wisdom Culture (Local Genius) as an Effort to Establish the Character of the Nation
}

\author{
Hasbi Ali ${ }^{1}$, Ruslan ${ }^{2}$ \\ Civic Education Faculty of Education and Teacher Training \\ Universitas Syiah Kuala \\ Aceh, Indonesia \\ 12asbysagita@yahoo.co.id, ${ }^{2}$ ruslanaceh@yahoo.co.id
}

\begin{abstract}
Actualization of the national life as an effort to develop citizenship to realize citizens who have character and have an understanding of citizenship one of those can be done through the preservation of culture of local wisdom. Problems occurred in this study were: (1) Re-inventory local wisdom culture that had ever grown and developed in society in Simeulue District, and (2) The efforts of preserving local wisdom culture by Acehnese Adat Council (MAA) of Simeulue District. This study used a qualitative approach with a type of descriptive research. The informants in this study were 5 people from the administrators of the Acehnese Adat Council (MAA) of Simeulue District, 3 traditional leaders, and 2 indigenous people. The results showed that (1) local wisdom that were still alive and preserved in the Simeulue Regency community such as Nandong (a hummingbird that accompanies a drum), debus (martial arts using sharp weapons), sikambang (dance in pairs), tari gelombang (dance performed by many people which is carried out to welcome the bride and to welcome honored guests), marangkul (procession before the bridegroom rises to the house the bride is pelted with yellow rice), buai (humming accompanied by dance to lull children), and tari pedang (dance arts using sharp weapons) and (2) The efforts of preserving by Acehnese Adat Council (MAA) of Simeulue District which was done through socialization into the community, but has not been maximized because of the limited number of personnel and funds problems. Conclusion: (1) In Simeulue District there are many local wisdom cultures such as nandong, debus, sikambang, tari gelombang, marangkul marapulai, buai , and tari pedang; and (2) Preservation of the culture of local wisdom in Simeulue District is carried out through socialization.
\end{abstract}

Keywords—culture of local wisdom; national character

\section{INTRODUCTION}

Local wisdom culture is one of the means of forming national character. Local wisdom according to Wales in Rosidi interpreted as: "The ability of local culture in the face of foreign cultural influences when the two cultures are related [1]. This is especially important in this era, namely the era of information and communication that if not addressed properly will result in the loss of local wisdom as identity and national identity. The same was said by Lubis that: "Ethnic identity is a cultural character" [2]
As for the local culture in Simeulue District, Aceh Province has been experiencing degradation with the development of Science, Technology and Art (IPTEKS). There are many varieties of Simeulue culture that have been degraded, even worried about extinction such as naïf-nafi (folklore), nanga (cultural speech), nandong, Sikambang (traditional dance which tells the life of local people both in the past, which will come loaded with values for human life today).

Much research has been carried out on local wisdom. Local wisdom in Bangkhunsai can be observed by way of traditional life such as work, relationships within society, as well as spiritual beliefs and practices that serve to promote the use of natural resources honestly, fairly and sustainably [3]. The importance of integrating cultural values of local wisdom (Rambu Solo) in the learning process as a forum for character formation or student identity [4]. Huyula's local wisdom culture contains Pancasila values that form the basis for character building nation [5]. Local wisdom can be approached from values that develop in it such as religious, ethical, aesthetic, intellectual, economics, technology, and others [6]. In fact the Indonesian people already have the qualities they have such as mutual cooperation, tolerance, mutual respect and hard work reflected in the local wisdom of the ethnic groups in Indonesia [7].

Therefore, this study would like to examine in more depth how the efforts to preserve the culture of local wisdom by the Adat Council to the younger generation in Simeulue Regency, so that cultural values can still be maintained as local wisdom of the local community.

\section{RESEARCH METHODS}

\section{A. Approach and Type of Research}

This research used qualitative approach, while the type of research was survey. The selection of approaches and types of research was in accordance with the issues to be studied, namely Efforts of Acehnese Adat Council Preserving Culture of Local Wisdom in Simeulue District. 


\section{B. Research Site}

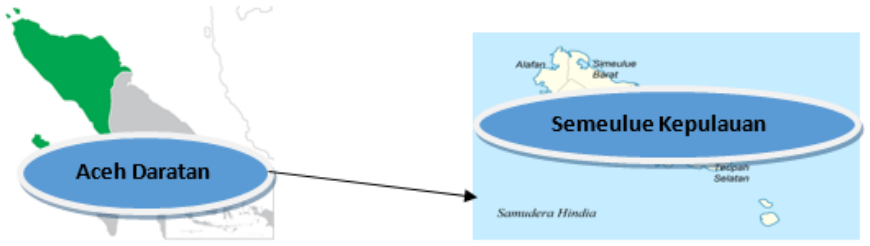

Fig. 1. Research site

The focus of this research was on the preservation of local wisdom culture in Simeulue District. Simeulue District is one of the districts in Aceh Province located at $150 \mathrm{KM}^{2}$ off the west coast of Aceh with coordinates point 2036 LU-9605BT and 2,60LU-96,0830BT. Simeulue District was established on 4 October 1999 consisting of 10 districts, namely Simeulue Timur, Simeulue Barat, Simeulue Tengah, Simeulue Cut, Teupah Barat, Teupah Selatan, Teupah Tengah, Teluk Dalam, Salang and Alafan consisting of 138 villages. Simeulue District with an area of $2,125.02 \mathrm{KM}^{2}$ is inhabited by 82,648 people. A population density of 38 people per square kilometer.

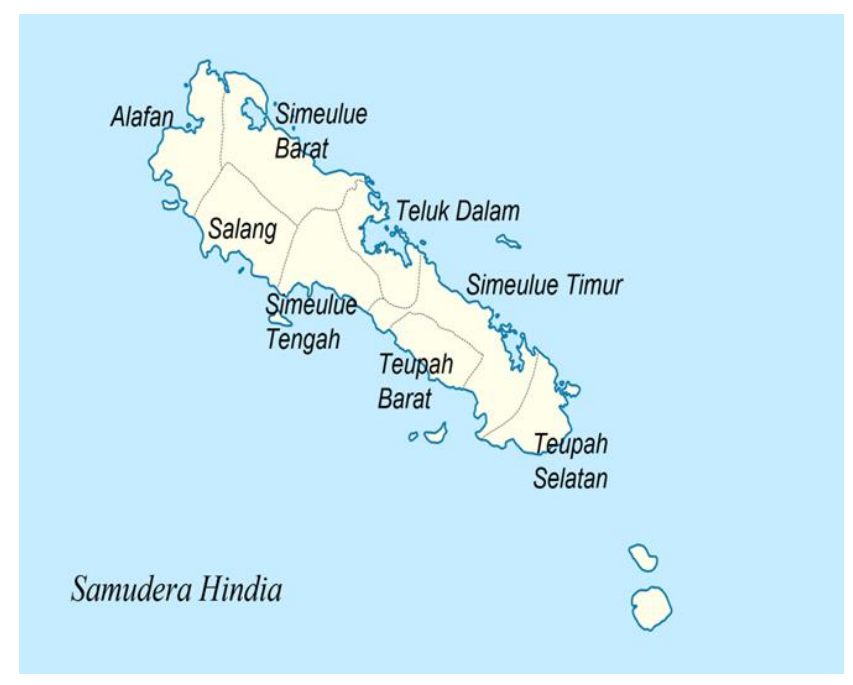

Fig. 2. Map of Simeulue District (Source: Wikipedia).

\section{Subject and Object of Research}

In deciding the subject in this study was conducted by Purposive Sampling (sampel bertujuan). In this study, the subjects of the study were 5 people from the administrators of the Acehnese Adat Council (MAA) of Simeulue District, 3 traditional leaders, and 2 indigenous people. Total subjects in this study were 10 people who knew about the growth and development of local wisdom culture in Simeulue District.

\section{Data Collection Research Techniques}

Data collection in this study was conducted through structured interviews based on the Interview Guidelines previously prepared by the Research Team and Peer Group. Questions raised in an interview related to Cultural Conservation of Local Wisdom in Simeulue District. The information that will be collected in this research include:
Cultural Data of Local Wisdom and the main obstacle faced by Simeulue Regency government in Cultural Preservation of Local Wisdom.

The information to be collected includes:

- Re-inventory local wisdom in Simeulue District.

- The efforts of preserving local wisdom culture by Acehnese Adat Council (MAA) of Simeulue District.

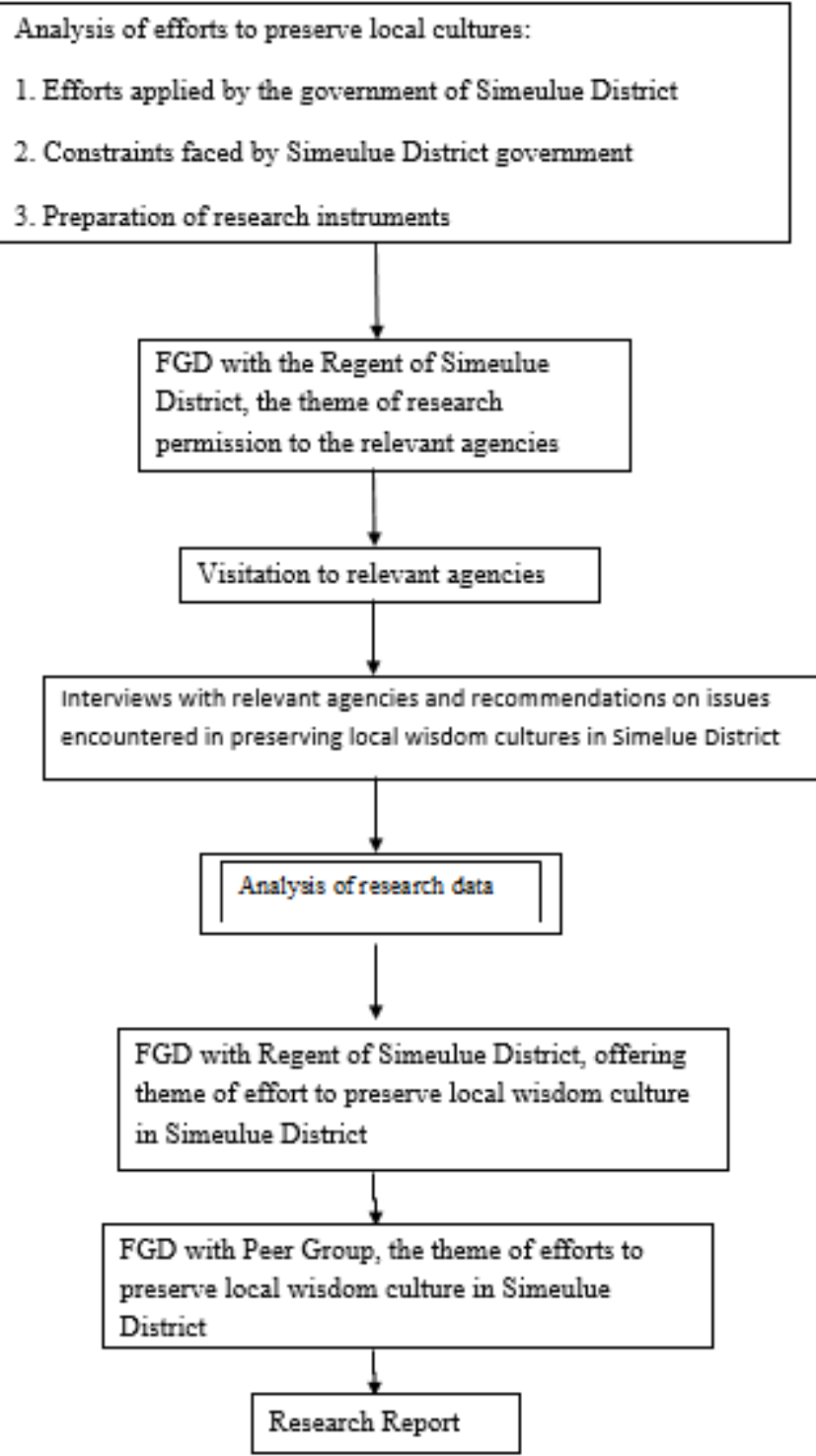

Fig. 3. Flow chart of research.

\section{E. Processing Technique and Data Analysis Research}

After data collected through interview, then the data was analyzed qualitatively with the following steps: (1) Data reduction, that is simplification and selection of data in accordance with the problems to be studied, (2) Presentation of data, that is descriptive data collected in narrative, and (3) 
Conclusion / verification which is the final step of analysis of research data.

\section{RESULTS AND DISCUSSION}

There are many kinds of local wisdom culture that have ever existed in the District of Simeulue, but the informants in this study did not know all of them. All local wisdom culture that have ever grown and developed in Simeulue Regency in practice could be seen at marriage ceremony, khitanan (circumcision), and also to build a new house.

The results of the studies found that there are still some local wisdom cultures that are still preserved by the people in Simeulue District like nandong (humming accompanied by drums), debus (martial arts using sharp weapons), Sikambang (dance in pairs), tari gelombang/wave dance (the dance performed by many people is done both to welcome the bride and to greet the honorable guest), Marangkul (procession before the groom goes up to the bride's house pelted with yellow rice), Buai (accompanied by a dance to lull the child) and Tari Pedang/sword dance (martial arts dance with sharp weapon). All of these local wisdom cultures are practiced in almost all areas, but there is not yet a single territory that remains a permanent establishment of the Acehnese Adat Council of Simeulue District.

The art of Nandong (rhymes that go along the drum) in the community of Simeulue District is one effective medium to express the feelings that are experienced both individuals and groups. The art of Nandong included in one type of art that has long been growing and developing in the daily life of the people of Simeulue Regency. When the art of Nandong is compared with the others culture of local wisdom in the district of Simeulue is one of the society's favorite

Nandong arts can be played by individuals or groups with poems that are sung to have their own levels between each other. In general, if the art of Nandong played by the group first begins with saramo (beat together) which is the beginning to find the appropriate tone. After saramo then the performing arts of Nandong begin to enter the stages in accordance with their levels, namely pantun (traditional poetry), serak (irregular), samba (reverence), rantau (tells about life abroad), kasih (as a form of longing for someone or desire for something), and izin (the end of the art procession of nandong).

This art of nandong only played by men, while women are involved in many arts nanga-nanga and buai. Nowadays, the art of nandong is being modified, not only accompanied by kedang, but also accompanied by the violin and the flute. In addition, nandong lyrics initially use Minang language, but currently modified using the language of ulao although somewhat ambiguous and often facing difficulties to understand.

Kedang or the drum is a musical instrument at this type of membranophone double head is in the form of cylinder or tube, where both sides are not equal. The musical instrument is made of wood that is hollowed out in the middle and covered by goat skin which has dried and cleaned its feathers as a membrane. On both sides the right and left membranes are fastened with rattan. However, today the makers of kedang use nylon straps as a substitute for rattan where it can precisely eliminate the value of authenticity.

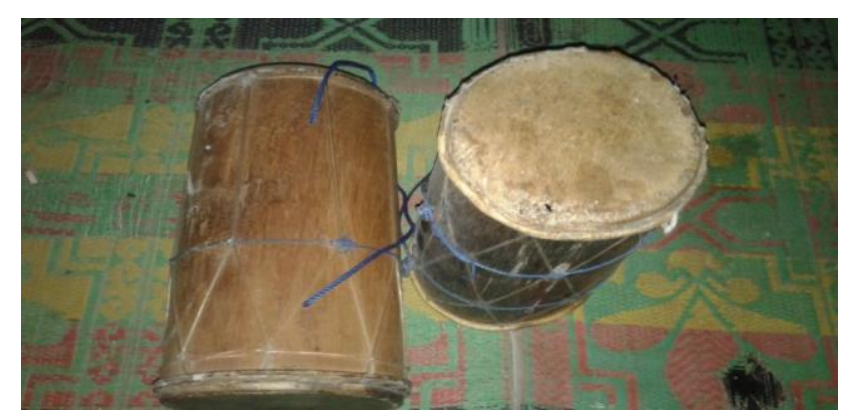

Fig. 4. A pair of Kedang.

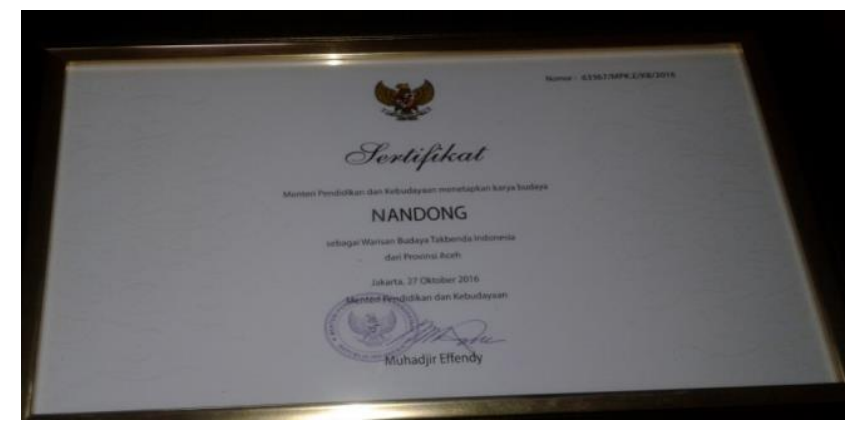

Fig. 5. Nandong certificate.

In Simeulue District, based on the statement from the Chairman of the Acehnese Adat Council of Simeulue District, Mr. Syamsuir Djam, that the art of Nandong is still very strong in the people of Teluk Dalam District of Simeulue Regency. The drum used is made of chosen wood with the typical architecture of Simeulue at first, but recently there have been public concerns because the drums are made only of PVC pipes sold on the market without any meaning of any local wisdom.

From many cultures of local wisdom which are still preserved in the community, one of which became the center of attention of the Acehnese Adat Council of Simeulue Regency is a Marriage Procession. The commitment of the Acehnese Adat Council of Simeulue Regency has also received a full support from the local government, so that in 2014 the Mastery Book of Custom and Marriage Association of Simeulue District of Aceh Province was successfully established.

The custom of marriage in the community of Simeulue district is divided into 2 (two), namely Bano and Јamu marriage. Indigenous marriage of Bano is divided into two areas, namely Region I includes East Simeulue Subdistrict, Teupah Selatan Subdistrict, Teupah Barat Subdistrict, and Teupah Tengah District and Region II covering District of Simeulue Tengah, Salang Sub-District, Simeulue Barat Subdistrict, Teluk Dalam Sub-District, Alafan Sub-district and Simeulue Cut Sub-district.

The fundamental difference of the adat bano marriage procession is that in Region I there is a term used, namely Mangeneng Adat / Paladang Sataun Duo (the temporary groom in the bridal house until they are able to live independently) is a long-standing local culture of wisdom and 
developed in bano defayan society to be followed and obeyed by every groom. Meanwhile, Adat Bano is in Region II on the contrary, where the bride follows and resides in her husband's house.

In the marriage procession that has been growing and developing in Simeulue District is a marangkul (throwing the bride with yellow rice). In this marathon activity the groom before going up to the bride's house must first follow the process of being thrown with yellow rice by the elder person (adat leader) accompanied by the reading of the Prophet's Prayer and other Prayers and pantun-pantun nasehat (traditional poetry containing advices) which aims to the happiness of the bride and groom later in undergoing the household life. This procession ends with the expression of approval from the bride's family: Naiklah si marapulai kami, $i k o$ janjangnyo (come forward our bride, this is the ladder).

In addition, in the procession of marriage there is one more thing that is very unique in the culture of local wisdom that developed in the district of Simeulue, the mamuai belek (opening the door of the bride's room to be juxtaposed with the groom). Where, in order for the groom to enter the bride's room first begins with a verbal communication between the talangkai (the person representing) the bridegroom with the wife laulu (mother's uncle) the bride who has been waiting at the door of the bride's room.

Talangkai greeted laulu's wife who guarded the door of the bride's room which only closed with a long cloth curtain saying: Assalamu'alaikum warahmatullahi wabarakatuhu. Then the man at the door answered by saying: Wa'alaikum salam warahmatullahi wabarakatuhu. Furthermore, the person outside said again: Itaya ame lion ek matan belek iye tuo, tolong mefuai kajap? (Who's in front of the room door Mam, please open for a while?).

Next, the person inside said: Anga aduon amuaianne, adu mai fuai (If there is no opening, we do not open the door). The person outside answered: Alek amuaianne, tuo (There's the opening, ma'am). Then the person who was inside answered: Dai ma'a anga wiye, miale meria bahak (If that so, please go inside) while opening the door curtain. Then couples with the groom enter the bride's room for juxtaposition.

There is one more unique thing in the marriage procession in the community in Simeulu district, which is the function of "cigarette" as a means of "social interaction". After joining in the bride's room, the next bride is brought outside sitting in front of relatives, village officials, and other invitees to listen to advice. Where, before the advice of the bridegroom first presents the betel or cigarettes present in the bongkoi (bundle of yellow cloth) as a form of honor to the simato (in-laws) and other customary law communities. This advice given in Simeulue society is called by the term Bulawan singa bakduon matot (Gold which will not be inexhaustible).

The procedures of marriage procession in Simeulue Regency in accordance with the agreement of both parties are as follows:

- Panggil suruik (calling back) with the term manyancang balandasan bakato batumpuan, malompek basitumpu, baimbau basautan (to chop there is a prop, to mumble should have a purpose, jump with the horses, call each other mutually).

- Karajo satafan (the event where the bridal groom and the bride are made into one place according to agreement with both parties).

- Tek tetae me tub belek (from the front room into the room).

- Manunang sambel mangadok (to propose and meet), where the groom after marriage stay at the bride's residence for good.

- Malayu tek uyul (already withered from shoots), where this is meant to the nomad male who do not have a family want to marry a local girl, until men are required to first find or determine his guardian in the area in accordance with the term Tabang maninggah dahan inggok manampu dahan (fly stepping on the branches, perch stepping on the branches too), where the family left behind by the man overseas, as well as the one he encounters in this new place is a family.

In addition to the procession of marriage, also the culture of local wisdom that is still preserved in the District of Simeulue is peusejuk (to give blessings in the sacred ceremony). The use of many words in Minang language indicates that the people of Simeulue Regency are culturally influenced by the culture brought by the Minangkabau people who have migrated to Simeulue since ancient times.

The Acehnese Adat Council of Simeulue District strives to preserve the culture of local wisdom by conducting socialization to the villages, particularly on the documented local culture of wisdom, the Custom Marriage of Simeulue Regency. However, in order to preserve the local wisdom culture that once grew and flourished in Simeulue District, the Acehnese Adat Council of Simeulue Regency experienced many obstacles such as very limited budgets, lack of operational transportation, and difficulty in getting the community to follow the socialization of local wisdom culture in Simeulue district.

In this case, the Acehnese Adat Council of Simeulue Regency continues to try to overcome these obstacles such as coordinating with the local government at both the district and provincial levels. Actually, the Acehnese Adat Council of Simeulue Regency has appointed a special person in charge of the preservation of local wisdom culture that ever grow and develop, namely Bidang Pusako Adat (Traditional heirloom department) Pembina Khasanah Adat (The coach of Custom Treasure) by Mr. Rasidin and M. Saman also Depatment of Indigenous Studies and Development by Mr. Satri Mandala and Yusrian.

Nevertheless, currently the Acehnese Adat Council of Simeulue Regency has succeeded in documenting only one area of local wisdom culture that once grew and developed in Simeulue District, namely Marriage Custom and Rasam (Customary Law) in Simeulue Regency since 2014. The efforts to socialize the culture of local wisdom that ever grows and develops in Simeulue District by the Acehnese Adat Council of Simeulue District did not run regularly or scheduled, the 
socialization is very dependent on the availability of funds available. Therefore, the Acehnese Adat Council of Simeulue Regency can only conduct guidance and cadre independently from the local community.

The local government and other relevant agencies are basically supporting the preservation of local wisdom culture that once grew and developed in Simeulue District, but it seems that support is only halfhearted because it does not have a direct impact on the physical development of the region. It can be seen from the budget cuts proposed by the Acehnese Adat Council of Simeulue Regency, a lack of response to the various programs of the Acehnese Adat Council of Simeulue Regency, and proven that the Acehnese Adat Council of Simeulue Regency only has its office in a very simple old building with very poor condition of the building. Therefore, there is a need for permanent building provision considering the role and function of Acehnese Adat Council of Simeulue Regency in order to preserve local wisdom culture that has been growing and developing in Simeulue Regency for a long time.

Based on the results of research indicates that efforts to preserve the culture of local wisdom that ever grow and develop in Simeulue District only limited the initiative of the Chairman of the Acehnese Adat Council of Simeulue District Mr. Samsuir Djam alone. At the time of this research, Simeulue district had just inaugurated new regents and vice regents, so the Acehnese Adat Council of Simeulue district put a lot of hope in the new government in order to preserve the local wisdom culture that once grew and developed in Simeulue Regency as an ancestral heritage.

\section{CONCLUSIONS}

- In Simeulue District there are many local wisdom cultures such as nandong, debus, sikambang, tari gelombang, marangkul marapulai, buai, and tari pedang.

- Preservation of the culture of local wisdom in Simeulue District is carried out through socialization.

\section{REFERENCES}

[1] A. Rosidi, Kearifan Lokal dalam Perspektif Budaya Sunda. Bandung: Kiblat Buku Utama, 2011.

[2] B.Z. Lubis, "Potensi Budaya dan Kearifan Lokal Sebagai Modal Dasar Membangun Jati Diri Bangsa," Jurnal Ilmu- Ilmu Sosial, vol. 9, no. 3, pp. 339-346, 2008.

[3] K. Kongprasertamorn, "Local wisdom environmental protection and community development: the clam farmers in Tambon Bangkhunsai, Phetchaburi Province, Thailand," Manusya: Journal of Humanities, vol. 10, no. 1, pp. 1-10, 2007.

[4] E. Syarif, H. Hasriyanti, A. Fatchan, I.K. Astina, and S. Sumarmi, "Conservation Values Of Local Wisdom Traditional Ceremony Rambu Solo Toraja's Tribe South Sulawesi As Efforts The Establishment Of Character Education," EFL JOURNAL, vol. 1, no. (1), pp. 17-23, 2016.

[5] R. Yunus, Nilai-Nilai Kearifan Lokal (Local Genius) Sebagai Penguat Karakter Bangsa: Studi Empiris Tentang Huyula. Ed.1, Cet. 1.Yogyakarta: Deepublish, 2014.

[6] Sartni, "Exploring the Local Wisdom of the Archipelago: A Philosophical Study," Journal of Philosophy, vol. 37, no. 2, pp. 118, 2014.

[7] Alfian, The Potential of Local Wisdom in the Formation of Identity and National Character, Proceedings of the 5th International Conference on Indonesian Studies: "Ethnicity and Globalization, 2013. 